\title{
University as a global actor in the international system of the $21^{\text {st }}$ Century
}

\author{
Francisco Del Canto Viterale*
}

doi: http://dx.doi.org/10.18543/tjhe-6(1)-2018pp169-198

Received: 27.09 .2018

Accepted: 12.11.2018

\begin{abstract}
Since its foundation, the university has always been a relevant actor within the international system as the main producer and transmitter of scientific knowledge. Considered as a global actor and historically interrelated with multiple agents at the national and international level, the university must now face new and powerful challenges within the international context. Since the last decades of the $20^{\text {th }}$ Century, the world has entered a vertiginous path of transformation, driven by multiple and profound global processes that have generated significant changes in all the parameters of the international system and have prompted the creation of a new international system. The research problem that arises in this work focuses on studying whether this new international stage will mean an opportunity for the university as an international actor to assume new roles on a global scale or if, on the contrary, whether threats and pressures will erode its global position. The main objective of the present investigation is to analyze the role of the university within the changing world order of the $21^{\text {st }}$ Century and for this purpose it is proposed to know the main changes that operate in the current international system, to decipher how these new global trends affect the university and, understand how the university is reacting to these systemic changes. To achieve these objectives, an extensive literature review has been carried out within the fields of International Studies, Education Sciences, and other Social Sciences. Finally, it is expected to obtain as a result some concrete answers about the context, the impact and the reactions of the university to the modified international system to contribute to a much broader, complex and necessary debate regarding the future of the university as a global actor in the new international system of the $21^{\text {st }}$ Century.
\end{abstract}

* Francisco Del Canto Viterale (francisco.delcanto@fresno.edu / fdelcanto@jhu.edu), $\mathrm{PhD}$, is Project Coordinator at Fresno Pacific University (USA); Director and Visiting Professor of MA Program in Global and International Studies (Science, Tech, and Innovation) at the University of Salamanca (Spain); and Visiting Researcher at Johns Hopkins University (USA).

More information about the author is available at the end this article. 
Keywords: international studies and higher education; international scientific relations; internationalization of higher education; cooperation and competition in higher education; higher education in an interdependent world; international challenges to higher education; emerging topics in the higher education scenario worldwide.

\section{Introduction}

From its remote and somewhat confused beginnings in the Eastern world, through the creation of the first institutions in medieval Europe, to the closest modern configuration, the university has always been a relevant actor within the international system. At the beginning of the $21^{\text {st }}$ Century, the international system seems to be in transition and reconfiguration resulting in a modified world order. The end of the Cold War finished the bipolar scheme and has contributed to a period of profound change in the main systemic parameters of that order. In this new and convulsive international context, the university, which key features are being global in scope and historically interrelated with multiple actors at a national and international level, faces new and powerful challenges as an international actor. ${ }^{1}$

From the field of Educational Sciences and Social Sciences, there are many experts who approach and study the future role of the university within the changing international system. Mostly, these investigations are aimed at recognizing how the main changes that occur in the "international system" affect Higher Education and the university, as well as understanding the effects of the internationalization process that many universities have promoted in recent decades. Particularly, the field of study linked to Higher Education has made considerable efforts to analyze the role of the university on a global scale. ${ }^{2}$ At the same time, from Philosophy and other Social Sciences such as Sociology or Economics, there have also been approaches

${ }^{1}$ To be considered an international actor, it is necessary to have the capacity to generate or participate in relationships that are intentionally significant for the entire international system (Dallanegra Pedraza, 2001, 2003).

${ }^{2}$ Cf. Sheila Slaughter and Larry Leslie, Academic capitalism: Politics, policies, and the entrepreneurial university (Baltimore: Johns Hopkins University Press, 1997); Jürgen Enders and Oliver Fulton, Higher Education in a Globalizing World: International Trends and Mutual Observation (Dordrecht: Springer Science \& Business Media, 2002); Roger King, The University in the Global Age (Basingstoke: Palgrave MacMillan, 2004); James Forest and Philip Altbach, International Handbook of Higher Education (Dordrecht: Springer, 2006); Philip Altbach, Liz Reisberg, and Laura Rumbley. "Tracking a global academic revolution." Change March/April (2010): 30-39. 
made to understand the role of the university and the influence of the international context in its traditional functions. ${ }^{3}$ Along the same line, international organizations have also recently focused their research work on the intersection between higher education and international affairs because of the renewed interest in scientific knowledge and university training in the $21^{\text {st }}$ Century world order. ${ }^{4}$

On the other hand, there are relatively few investigations carried out from the specific disciplinary field of International Studies on the role of the university as an international actor. The historical interest and focus of the international discipline on the role and performance of the Nation State as a central actor of the international system has meant a certain abandonment and neglect of other global actors and phenomena, among which are higher education and, particularly, the university. Of course, this does not mean that there are no researchers from International Studies working on these issues, but they have not had the means to a profound analysis of the role of the universities in the international context. Among the few "internationalists" who have addressed the phenomenon, the interest has focused on understanding the changes within the "international system" and the impact that this has for universities. ${ }^{5}$ This paper tries to bring in innovative perspectives that address the role of the university from an International Studies viewpoint analyzing the mutual impact between international system and higher education institutions.

In the current international system, the university is facing many demands and challenges. As a result of that, the research problem that arises in this work focuses on studying whether this altered international stage will imply

${ }^{3}$ Cf. Henry Etzkowitz and Loet Leydesdorff, Universities and the global knowledge economy: a triple helix of university-industry-government relations (London: Pinter, 1997); Zygmunt Bauman, Liquid modernity (Cambridge: Polity Press, 2000); Boaventura de Sousa Santos, La Universidad en el Siglo XXI (Buenos Aires: Laboratorio de Políticas Públicas y Miño y Davila, 2005); Manuel Castells, Communication power (NY: Oxford University Press, 2009); Daniel Innerarity, La democracia del conocimiento (Barcelona: Paidós, 2011).

${ }^{4}$ Cf. UNESCO, 2009 World Conference of Higher Education: the new dynamics of higher education and research transformation and development (Final Report. 5 to 8 July 2009. Paris: UNESCO, 2009); UNESCO, UNESCO Science Report: Towards 2030 (Paris: UNESCO Publishing, 2015); OECD, Education at a Glance 2016: OECD Indicators (Paris: OECD, 2016); WORLD SCIENCE FORUM, Declaration of the 8th World Science Forum On Science For Peace (Text adopted on 10 November 2017, Dead Sea, Jordan).

${ }^{5}$ Cf. Immanuel Wallerstein, Geopolitics and Geoculture: Essays on the Changing WorldSystem (Cambridge: Cambridge University Press, 1991); Gilles Breton and Michael Lambert, Universities and Globalization: private linkage, public trust (Paris: UNESCO, 2003); Michael Horowitz and William White-Burke, "Academia can be an important vanguard of the Fourth Industrial Revolution”, World Economic Forum, 19 Jan 2018. 
an opportunity for the university as an international actor to assume new roles on a global scale or if, on the contrary, threats, and pressures will besiege it erode its global position. The main objective of the present investigation is to analyze the role of the university within this changed world order of the $21^{\text {st }}$ Century and for this purpose it is suggested to analyze the main changes that operate in the current international system, to decipher how these new global trends affect the university and, understand how the university is reacting to these systemic changes.

In terms of the methodology applied, a variety of sources are used for data collection and data analysis, which includes an extensive literature review within the disciplinary field of International Studies, Education Sciences and other Social Sciences.

Being aware of the breadth and complexity of the study phenomenon and the thematic, empirical, disciplinary and methodological limitations involved in a work of this caliber, the present research intends to contribute through a bibliographical study to encourage academic debate on the role of the university in the $21^{\text {st }}$ Century that requires new and more complex investigations.

\section{University as a national and international actor}

Historically, the university has been an institution linked to a wide range of national and international actors at different levels, as well as a varied agenda of social, political, economic, educational, technological and cultural issues. In the field of International Studies, the university has played a significant role throughout history, not only as a natural responsible for the production, systematization, and transmission of science and knowledge but also mobilizing transborder activities of professors, researchers and students from all over the world.

For two centuries, the university has been able to coexist with the central actor in international relations: the Nation State. Although it has received strong pressure from the modern Nation States that sought to nationalize their functions and turn it into an instrument of internal homogenization, the university has been able to interact with the Nation State to sustain certain spaces of autonomy. Faced with the demands of the State, the university was obliged to provide a training education for the citizen that would make disciplinary specialists also worthy patriots who would defend national causes. As Enders points out:

The contemporary university was born of the nation-state, following the establishment of clear national economic interests. Their regulatory and funding context was, and still is, national; their contribution to national 
cultures was and still is, significant, and universities played, and still play, a considerable role in what some have called the military-industrial complex of nation states. In this perspective, they are very much national institutions. ${ }^{6}$

However, a tacit agreement between the State and the university was generated which allowed certain autonomy and certain privileges in exchange for providing knowledge and skilled personnel that would contribute to the economic and military development of the nation. This agreement allowed university to protect the perspective as universalist and international force (because this is the nature of knowledge) even though it provided essential services for national agents.

During the Cold War, the confrontation between the two global superpowers was settled in the field of ideologies and this meant that many Nation States pressured the university in their countries to play an active role in the indoctrination of individuals, institutions, and countries. In this context, the university had to negotiate again with those States certain margins of independence in exchange for not only being responsible for the transmission of prevailing political ideas but also participating strongly in the struggle for economic and scientific-technological development. The end of the Cold War eased the pressure of States, but, at the same time, it opened a new stage in the history of international relations where the university will be subjected to new demands and challenges.

Throughout its historical evolution as an international actor, the university has demonstrated a series of attributes that are its own and define it as such. These particularities explain, to a large extent, their historical actions and, at the same time, allow us to foresee their capacity to respond to the multiple challenges that must be faced in the current international system. Essentially, it is possible to identify three characteristics that define the university within the world concert:

\section{1) Traditional actor of scientific knowledge}

Essentially, it is the institution that has the specific task of producing scientific knowledge and, therefore, what really defines the university nature is its historical role as a creator and transmitter of new knowledge. A pioneer in this field, John Henry Newman, has pointed out that the main purpose of the university is nursing "knowledge". In

6 Jürgen Enders, "Higher education, internationalization, and the nation-state: Recent developments and challenges to governance theory," Higher Education 47, no. 3 (2004): 364-365.

7 Gary Rolfe, "Cardinal John Henry Newman and "the ideal state and purpose of a university': nurse education, research and practice development for the twenty-first century," Nursing Inquiry. 19 (2012): 100. 
the same line, the French thinker, Foucault, believes that the university is a part of society that tries to respond to the will of humanity to understand the truth in all circumstances of life and the universe in which that lives. ${ }^{8}$ Finally, Altbach complements this view by pointing out that the university is: "the primary center of learning and reservoir of accumulated wisdom". ${ }^{9}$ Consequently, it is understood that the university has historically complied in the international system with the two central functions assigned to it: producing knowledge and transferring knowledge, which is educating people.

\section{2) Universal and international vocation}

Historically, the university has been characterized by an obvious universal vocation and an open promotion of the international. The nature of knowledge is universal and transcends national boundaries. Supported by these values, the university has always tried to develop technical and scientific progress that is transnational in scope. Therefore, it must be considered that the university has always been an internationalized institution where professors and students shared the most varied nationalities and where the mobility of international students was constant. Throughout history, many times universities have maintained contact even in the tensest moments of a relationship between States and in many others have been the first step in the reconstruction of a conflictive relationship through the signing of exchange agreements and scientific-technological cooperation. As Altbach points out, although there were other models of university institutional organization, the current universities become part of the medieval Western model, especially the one promoted by the University of Paris, which means that the organizational pattern of contemporary universities has a common tradition, which is the element of internationalization. Altbach sums it up by saying: "There is an institution that has always been global and that continues to be a powerful force in the world after half a millennium. With its roots in medieval Europe, the modern university is the center of an international knowledge system that embraces technology, communication, and culture". ${ }^{10}$

\section{7.}

${ }^{8}$ Michel Foucault, The archeology of knowledge (New York: Pantheon Books, 1972):

9 Philip Altbach, "Perspectiva comparada para la educación superior en el Siglo XXI," Revista Pensamiento Universitario, Año 6, Nro. 8 (1999): 3.

10 Altbach, "Perspectiva comparada para la educación superior en el Siglo XXI," 3. 


\section{3) Adaptation capacity}

The flexibility and ability to adapt to the innumerable political, social, economic and cultural changes are the elements that allow us to understand one of the keys to the thousand-year-old global existence of the university. Throughout its history, the university has shown an enormous ability to adapt to new contexts, actors and phenomena in the international system. Precisely, these qualities are what have allowed it to become one of the most long-lived international actors and, at the same time, most relevant to the global concert, maintaining its traditional role as an actor in charge of generating and transmitting scientific knowledge. The perdurability of the university as a historical and global institution within the international system comparing with other actors is evident. Its durability is confirmed by discovering that among all kinds of institutions that were established in the Western world by the year 1520 , only 85 still survive today, including the Catholic Church, the British Parliament, some Swiss cantons and more than 70 universities. ${ }^{11}{ }^{12}$ As Sporn concludes: "Universities have become the oldest type of organization in the world, surviving turbulent periods and epochs with different values, beliefs, and cultural norms. This suggests that his administration and governance have unique characteristics that allowed him to adapt to all the environmental changes that he has had to live". ${ }^{13}$

Essentially, the existence of the university for centuries as an actor of the international system has been associated with its role as the main producer and transmitter of scientific knowledge; its universal and global vocation; and its flexibility and ability to adapt to new times and contexts.

\section{New international context}

In the last decades of the $20^{\text {th }}$ Century, the world entered a vertiginous path of transformation, driven by multiple and profound global processes 115 .

${ }^{11}$ Clark Kerr, The Uses of the University (Cambridge: Harvard University Press, 2001),

${ }_{12}$ Among other examples, the University of Salamanca celebrated its 800th anniversary in 2018 .

${ }^{13}$ Barbara Sporn, "Governance and Administration: Organizational and structural trends," in International Handbook of Higher Education, ed. James Forest and Philip Altbach. (Chapter 9. Volume 18. Dordrecht: Springer, 2006), 141. 
that, in parallel, have been operating within the world order and have generated very significant changes throughout the international system: the transition from the Cold War to a new international order; changes in the capitalist economic system; a scientific and technological revolution; the globalization and the erosion in the role of Nation-States. This new context implies substantial changes in the international system, which have generated (and continue to do so) a structural transformation of the political, economic, social, technological, educational and cultural spheres that are shaping a new configuration of the world order of the $21^{\text {st }}$ Century.

It is possible to consider the current configuration of the international system as a structure in transition, from an old and simplified bipolar scheme typical of the Cold War towards a new, more polarized and complex international order. The international system is going through a stage of intersystem transition, ${ }^{14}$ characterized, mainly, by the speed, magnitude, and complexity of the change. While this transition within the current international system is a slow historical process and still in progress, it is equally possible to analyze some essential systemic parameters ${ }^{15}$ that allow describing the main changes and identify some initial characteristics of the new global order where the university could play an important role.

\section{1) Actors}

The first of the elements to be considered are the main actors that participate in global dynamics. In the current international order, it is possible to identify a wide range of actors that have very different characteristics according to their number, power, function, and interests. The international post-Cold War system has opened a new scenario where traditional actors of international relations coexist alongside new actors who acquire notoriety and where the Nation State is forced to interact with non-state actors that demonstrate a renewed interest. All these actors coexist in a disordered situation and are highly interdependent among themselves, which allows to foresee a reordering and rebalancing of the international system. In this sense, it is foreseeable that new polarization processes will take place where new actors (States and non-States) acquire relevance and

${ }^{14}$ The process of "intersystem transition" is called: "the stage that mediates between the "decadence "of a system and the" emergence "of a new one" (Dallanegra Pedraza, 2001, 2003).

15 The "systemic parameters" are all those elements and constituent parts of the international system (actors, relationships, processes, topics, etc.) that play a central role in determining the final configuration adopted by the world order. 
global power, while others lose their strength. ${ }^{16}$ Some of these new international actors began to challenge the traditional role of intermediation of the higher education institutions because they aspire to participate and link directly with scientific knowledge through their own production, transmission, and application.

2) Relationships

The second component to analyze in the current global context are the interactions and relationships that are generated between the different actors within the international system. The acceleration of phenomena such as globalization and the scientific-technological revolution and the presence of more international actors forming part of the international order are some of the factors that are shaping a new global structure where the interactions and relationships between the different actors shape new types and greater number of connections. The traditional interactions and relations between states (mostly bilateral) have given way to a new international scenario with a greater number of actors (both state and non-state) that make a greater number of linkages (multilateral, regional, international, transnational, etc.). This acceleration and intensification of the interactions and relations between the different actors are consolidating conflicting and asymmetric links, but, at the same time, increasing cooperative and competitive interrelationships between universities and a large variety of international stakeholders. ${ }^{17}$

3) Topics

The end of the bipolar order allowed the emergence of topics that were displaced or subordinated by security and defense issues and in the current international system, they have become much more relevant, which prompted the establishment of a new global agenda of topics characterized by being much more diversified, extensive and interdependent than the previous. Among the new issues that have become relevant are environmental issues, poverty, social inequalities, migration, global governance, or financial volatility. Higher Education, the training of skilled personnel, and the transmission of scientific knowledge to future employees and

${ }^{16}$ Essentially, "polarization" is a very dynamic process by which the main actors of the international system struggle and compete seeking to establish balances of power in the system.

${ }_{17}$ Since the end of the seventies, Robert Keohane and Joseph Nye (1977), began to describe the emergence of a new international system characterized, precisely, by the existence of new non-state actors interested in global affairs and the acceleration of intensification of contacts between them, which was generating a new context of "complex interdependence". 
citizens have claimed in the top of the agenda of topics in the international system.

4) Processes

Finally, a set of international processes that profoundly affect the totality of international reality and its most essential parameters (political, economic, technological and social) have arisen in a disorderly, interdependent and overlapping manner. Within this new international context, some systemic processes are affecting especially the functions and roles that the university has historically had. The following stand out among them:

\section{i. Transition to a new ordering of the international system}

The culmination of the Cold War has assumed the exhaustion of the bipolar international order that extended from the end of the Second World War until the definitive dissolution of the communist bloc in 1991. The central issue in this process is the magnitude of the change produced by the transition to a new ordering of the international system. The fall of the bipolar structure supposes, at least, three main consequences on the international configuration of post-Cold War: a) the collapse of one of the superpowers (the Soviet Union) leaves the United States as the main actor of the international system a single political and economic referent, but also supposes the emergence of new poles that aspire to balance the power of the hegemon (China, India, European Union, etc.); b) the end of an international agenda of topics marked by military issues that gives space to the treatment of new topics; c) the end of the strategic alignments in a bipolar key and the disciplined subordination of the actors to one of the antagonistic blocks. The new international order of the $21^{\text {st }}$ Century is changing dramatically, and it could open numerous opportunities for universities.

\section{ii. Erosion of the Nation State}

The second process of special relevance generated within the international system in recent decades is the erosion of the traditional role of the Nation-State and the consequent changes in the international political order. The Nation State has begun to lose power and influence within the world order because of a confluence of factors: a) growth of the influence of the communication, information and finance sectors that operate over the borders of the Nation-State, and b) by the increase of local and subnational identities. As a result, questions have been raised 
about the continuity of the Westphalian Order and, for the first time in hundreds of years, the Nation State feels its position as a central actor of the international system threatened, which necessarily implies a change in the international political order. ${ }^{18}$ This erosion of the Nation State has, at least, two visible impacts on the university: on the one hand, the increases of the number of international non-state actors with a hegemonic vocation that rival the university; and, on the other hand, the Nation State has begun to reduce national budgets for universities leaving part of this task in private hands. ${ }^{19}$

\section{iii. Changes in the capitalist economic system}

Another process within the international system to consider is linked to changes in the capitalist economic system. The supremacy of the capitalism throughout the $20^{\text {th }}$ Century has only been possible thanks to the fact that, throughout its historical evolution as an economic model, it has mutated, reconverted and reconfigured several times to maintain itself in force. One of the most important changes occurred at the beginning of the 1970s when the economic guidelines established at Bretton Woods were modified towards a mode of subordination of domestic economies to the demands of the global economy. From then on, the formation of an international economy characterized by the globalization of production and finance thanks to the use of new technologies became increasingly evident. These changes in the economic system began a new stage of capitalism that was transformed into an essentially post-industrial and post-Fordist economy, which meant the change from a production system based on the industry governed by corporations, unions and state regulation to the production of management without industry (in terms of territorial location) and without regulation, constituted by the actions of companies and the competition between them. The economy is increasingly outsourced, focused on the intensive use of intellectual capital, increasingly globalized and much more flexible and mobile thanks to the use of the new Information and Communication Technologies (ICTs). In this context, scientific

18 The "Westphalian Order" refers to the system of political organization based on the principles of territoriality and sovereignty of the Nation State that has remained in force for the last 350 years in the international system.

19 UNESCO, UNESCO Science Report: Towards 2030, 41. 
knowledge has been revalued as a key input for market innovation, which places the university in a strategic position as a traditional international actor in the production and transmission of knowledge. In the capitalist economic system of the $21^{\text {st }}$ Century, the generation of knowledge and the qualification of human resources become essential economic tasks.

\section{iv. Scientific-Technological Revolution}

The spectacular scientific and technological development of the last decades is generating the impression of living one of those key moments in the history of humanity. It is a revolution that affects the very foundations of the system and that, at the hands of an unparalleled scientific-technological development, is modifying each aspect of our life. The expression Scientific-Technological Revolution refers to the phenomenon of technical transformations and their economic and social implications that have occurred within the international system since the last quarter of the $20^{\text {th }}$ Century up to the present. The speed and depth of the intensive application of new technology to numerous areas of daily life make it difficult to assess the impact that all these changes are generating on society. Therefore, it is possible to describe some of the most visible transformations: a) the enormous range of possibilities for research and development in new areas of knowledge; b) the emergence of new industries and sectors of goods and services; c) the dematerialization of manufacturing and commerce; d) the elimination of barriers to the cross-border circulation of goods, services and capital; and, e) changes in referents of time and space that are totally discarded in the traditional way. According to Schwab "These new technologies have the potential to change the course of history and affect every aspect of our lives". ${ }^{20}$ The application of technology to the treatment of information and communications has a strong impact on universities and is forcing them to modify and adapt a large part of their activities. The rapid scientific-technological development of recent years has forced the university to make quick decisions due to the impact that these changes are having on teaching, on research, on the development of a new virtual market and by the emergence of new actors-competitors, among others.

${ }^{20}$ Klaus Schwab, The Fourth Industrial Revolution (New York: Crown Business, 2016), 2. 


\section{v. Globalization}

The analysis of the current international context would not be understood without taking globalization into account as one of the most recognized processes in the current global context. It is a phenomenon of multi-causal origin, of enormous proportions and with unpredictable consequences for the entire international system. During the first half of the 1990s, and despite the imprecision of the new world context that was beginning to emerge, a consensus gradually emerged that globalization was a key factor in the transformations that the international system was undergoing. This is what David Held (2000) defined as the "expansion, deepening and acceleration of the global interconnection in all aspects of contemporary social life". A more interconnected and interrelated world, at least in some areas (in economic, financial and communication terms), and in some specific geographic coordinates (developed countries). Regardless of the position taken on the controversial phenomenon that globalization entails, what is certain is that its effects are permeating the new world reality and, especially, are spreading in the field of action of higher education and the university. As Knight points out, the result of this whole process draws a new scenario for higher education institutions with very particular characteristics: a) the use of English as a lingua franca of scientific communication; b) the growth of the international labor market for professors, researchers and students; c) the use of new technologies for better communication and exchange of data, the selection of personnel, the dissemination of scientific knowledge; d) the generation of research networks, and also e) the realization of academic programs of virtual learning. As Knight summarizes: "Globalization must be understood as a key contextual factor that has multiple effects, both positive and negative, in the field of education". ${ }^{21}$

\section{vi. Beginning of the Knowledge Society}

Finally, in this convulsive context of the beginning of the $21^{\text {st }}$ Century, knowledge and science acquire special and strategic relevance as a global agenda topic. The role observed is playing scientific knowledge in the current stage of the international

${ }^{21}$ Jane Knight, "Internationalization: Concepts, Complexities and Challenges," in International Handbook of Higher Education, ed. James Forest and Philip Altbach (Chapter 11. Volume 18. Dordrecht: Springer, 2006), 207-227. 
system has overflowed the strictly economic scope to transfer to the rest of society generating an extensive and powerful impact in all spheres. In this context, the phenomenon of the Knowledge Society refers to a new type of society characterized by the intensive application of knowledge in all the orders of life and where knowledge becomes the main source of production, wealth and power. The emergence of the Knowledge Society is a global process that will not totally replace the old Industrial Society but will coexist in a range of heterogeneous situations during a long period of transition. Everything presumes that the road to a true Knowledge Society will be a slow, complex, heterogeneous and conflictive process, which will depend, in large part, on the ability of the actors to extend the benefits of the new era of knowledge to the whole international society. In this context, the university, as a traditional actor of knowledge, can occupy a very prominent role in the future international system.

\section{Impact and challenges for the university}

The profound changes that have taken place in the international system of the $21^{\text {st }}$ Century are having important consequences and impacts on the university. The ability of survival and the adaptability that the university has shown throughout its history are its main strengths to face a changing international context where new actors and interests have begun to challenge the university in its traditional functions. King describes the new international context that awaits the university by stating that: "the decline of sovereignty and influence of the territorial states, and the growth of international and supranational jurisdiction, alongside the increased globalization of world economy, also heralds, if not the end of the University, then its profound transformation". 22

In the world order of the $21^{\text {st }}$ Century, so uncertain, changing and complex, the university will have many obstacles to face. Among them, it is possible to identify, at least, five main challenges:

1) The proliferation of new international actors challenging the role of the university

The first of the challenges that the university must face, in the current international system, is the proliferation of new international

${ }^{22}$ Roger King, "The contemporary University," in The University in the Global Age, ed. Roger King (Chapter 1. Basingstoke: Palgrave MacMillan, 2004), 1-2. 
actors that aspire to participate and link directly with scientific knowledge through their own production, transmission, and application. This is what de Sousa Santos calls the "crisis of hegemony" ${ }^{23}$ of the university, which means to stop being the only actor in the field of Higher Education and in the production of scientific research due to the appearance of new competitors who perform the same functions as during centuries were almost exclusively the university's task. In this sense, it is almost unanimous among experts the consideration that the new international context is working against the traditional monopoly held by the university in the creation, management, and transmission of scientific knowledge due, among other things, to the increase in the number of actor's international organizations interested in linking directly with knowledge. Actors such as Companies, Intergovernmental Organizations, Non-Governmental Organizations, Think Tanks, Epistemic Communities or Scientific Diasporas have become virtual competitors of the university. Due to this, thinkers such as Wallerstein openly raise their doubts about the future of the university asking whether in the next fifty years the university will continue to be the main organizational basis of academic research or other structures (research institutes, center of advanced studies, epistemic communities, companies, etc.) will replace it. ${ }^{24}$ Given this scenario, many experts are already beginning to proclaim a new international context "polycentric of knowledge" 25 or "pluricentric" 26 where the university must share roles and functions with new actors.

2) Get wider margins of autonomy and independence

The second challenge facing the university within the new international system is to maintain certain margins of autonomy and independence. What de Sousa Santos calls "institutional crisis" is the growing pressure to which the university is subjected to adapt to criteria of efficiency and productivity of a corporate nature or social responsibility. The revaluation of Science, Technology, and Innovation as a strategic resource is increasing the attention and interest of the

${ }^{23}$ de Sousa Santos, La Universidad en el Siglo XXI. Para una reforma democrática y emancipadora de la Universidad, 12.

${ }^{24}$ Immanuel Wallerstein (coord.), Open the Social Sciences: Report of the Gulbenkian Commission on the Restructuring of the Social Sciences (Stanford: Stanford University Press, 1996).

${ }^{25}$ Daniel Innerarity, La democracia del conocimiento. Por una sociedad inteligente, 61.

${ }^{26}$ Oliver Todt, "La gobernanza tecnocientífica en la Unión Europea," Revista CTS, Vol. 3, No 7, (Septiembre 2006): 24. 
environment (economic, political and social) on scientific knowledge and is increasing the demands and pressures on the university itself. Breton describes this situation very well when he points out that: "Universities are now subsumed to the economy and the market, losing the autonomy that they enjoyed at other times, to join knowledge production networks in which the academic decisions begin to be taken from other motivations". ${ }^{27}$ Even areas that seem to be far from the university context, such as the strategic-military or the ecological one, begin to pressure the university in search of specific solutions for their own conjunctural problems and challenges. Most of the current debates, both academic and non-academic, point out the need for the university to articulate its functioning with other international actors (State, Company, International Organization, etc.) to achieve greater economic, political and social development. These new ways of connecting and articulating new actors with the university do not cease to be a serious threat to the autonomy in the functioning of the universities. According to Altbach and Knight, universities are now more closely linked than ever to the practical needs of society dictated by governments (for public institutions) and the market (for public and private institutions), which means that the pendulum has too decanted towards the government and the market, at the expense of the traditional autonomy of the academic world. ${ }^{28}$

3) Assignment of new roles and functions

The third challenge that higher education institutions must face is the assignment of new roles and functions. Historically, the university has complied with the two central functions assigned to it: generating scientific knowledge and educating people. However, now, the university is being subjected to strong pressures both from the environment and in its interior to deepen some of its old roles and, at the same time, assume new functions within the international system of the $21^{\text {st }}$ Century. In this regard, it is possible to identify at least three systemic demands.

First, amid global changes and emerging tensions, the university is now under pressure to expand and deepen its role as the main actor in the task of educating people and instructing future professionals. This is an activity that the university has historically carried out, but which

27 Breton and Lambert, Universities and Globalization: private linkage, public trust.

${ }^{28}$ Philip Altbach and Jane Knight, "The Internationalization of Higher Education: Motivation and Realities," Journal of Studies in International Education, 11 (2007): 290-304. 
now acquires greater importance due to the revaluation of knowledge and the qualification of personnel for the economic system. Currently, the most important function of the university is to produce welltrained and highly mobile skilled workers who can act as vehicles for the transfer of technical and scientific knowledge. The work of reproduction of highly skilled personnel becomes one of the central activities for the new Knowledge Society since these qualified workers will be responsible for tasks related to the creation of knowledge through research, both in the public sphere as private; they will be responsible for the transmission and reproduction of tacit knowledge through teaching; and, they will also manage the transfer of knowledge to the productive sector to turn knowledge into innovation..$^{29}$

Second, the university is being pushed to become a new source of scientific and technical solutions to the multiple global challenges that humanity must face. There is a consensus today that no other actor is in a better position than the university itself, given its history, nature, and objectives linked to scientific knowledge, to be able to respond to the complex international agenda that must be faced in the $21^{\text {st }}$ Century. The need for scientific knowledge to be used as a tool to solve the global challenges in the current historical moment, which transcends national borders, is frequently raised from some political, economic, social and academic areas. In this sense, the university is understood as the most useful and effective instrument in the search for concrete solutions to the global threats that the international agenda of topics present today (environmental problems, energy, poverty, inequalities, massive movement of people, public health issues, etc.) through the creative application of scientific knowledge for the solution of general problems.

Finally, the university is also assigned a role linked to the need to share the result of its tasks with other social actors through specific applications and, especially, by transferring its research to the productive sector as a way of contributing to the economic and social development. Universities are being subjected to strong external pressures to expand their role and extend their links outside the traditional academic environment because it is understood that the role of universities is especially strategic in the new global context.

${ }^{29}$ Innovation is understood as a process of creating economic value through which certain products or production processes are effectively introduced into markets (OECD and Eurostat, 2006). 
This is the origin of the so-called "Third Mission" of the university, for which it must fulfill a new function in the Knowledge Economy and Knowledge Society linked to contribute to economic and social development through the production and transfer of knowledgebased innovations. This function is added to the two performed by the traditional Humboldt university of teaching and research.

\section{4) Extension and naturalization of competitive logic}

A fourth challenge comes from the entrance of the university into the competitive logic of the capitalist economic system. In the current international context, universities represent a fundamental resource in the new Knowledge Society because they are a key element as centers of training, creativity, innovation, entrepreneurship, transfer, and attraction of investments and talents. As a result of this revaluation, it is not surprising that the university centers have also entered the competitive logic that characterizes the world capitalist system. Therefore, now universities have become global actors that, increasingly, compete to attract funds, professors, researchers and students because the reputation of a university is now built internationally which means competing with other institutions at local, regional and global level.

Competition between universities has been institutionalized within the global market thanks to the accreditation systems (ISO quality mark) and evaluation (hierarchy of results) made by public and private agencies at different scales. The most visible aspect of competitive internationalization is the recent appearance of world university rankings, which represent one of the most evident effects of academic globalization. These rankings demonstrate explicitly the competitiveness of a university through the comparison with their peers on a series of criteria that are normally linked with the infrastructure, the academic offer, the teaching quality, the research prestige and the scientific production in publications and patents, among other indicators. ${ }^{30}$

The extension and naturalization of competitive logic among higher education institutions is a controversial phenomenon for many experts who show discrepancies about the consequences of this open

${ }^{30}$ Although numerous university rankings have proliferated, the three most renowned and most influential are: i) the Annual Academic Ranking of World Universities (ARWU) published by the Institute of Higher Education of the Jiao Tong University of Shanghai (UJTS) in China; ii) the Academic Ranking of World Universities, of the Times Higher Education Supplement (THES) of London; and, finally, iii) the Quacquarelli Symonds (QS) World University, published by the British company Quacquarelli Symonds. 
competition. For some intellectuals, the entrance of the university into commercial and competitive logic directly attacks the very nature of university activity and can only be understood within the framework of a process of commercialization of scientific knowledge. In this line, de Sousa Santos points out the existence of a neoliberal project in the medium and long-term, which includes different levels and forms of commercialization of the university based on two pillars: the reduction of investment of the Nation-State in the public university and the commercial globalization of the university. The final objective of this process is none other than the transnationalization of the university educational services market. ${ }^{31}$ On the contrary, for other specialists, this competition is necessary and beneficial for the university. Quintanilla, for example, criticizes those who understand the competitive logic of universities as an imposition of the capitalist system and believes that competition can bring out the best in universities, scientists and students: "Even if we had a social economy instead of a capitalist one, it would continue to be necessary, in order to guarantee the progress of science and technology and, consequently, the increase in the well-being of the population, that European universities compete among themselves for being better and better, or for attract the best scientists and students". ${ }^{32}$

5) Increasing unequal geopolitical distribution among universities

A final challenge is represented by the increasing inequality in the geopolitical distribution of universities within the international system, which is generating the intensification of the knowledge and scientific gap, as well as the deepening of the processes of "centrality and marginalization" of universities at international level.

In the new international system, universities are distributed and concentrated in a small number of global institutions, called World Class Universities, which are those that occupy the top positions in the rankings and have the best professors, researchers, and students. Currently, international rankings reveal a geographical distribution of such universities in just over ten countries, with a special concentration in the United States (between 50\% and 60\%).

The block of Anglo-Western universities (United States, United Kingdom, Australia, and Canada) and the rest of Western Europe,

${ }^{31}$ de Sousa Santos, La Universidad en el Siglo XXI. Para una reforma democrática y emancipadora de la Universidad, 16.

${ }^{32}$ Miguel Quintanilla, "La investigación en la sociedad del conocimiento." Revista CTS Vol. 3, núm. 8, abril (2007):186. 
cover $93 \%$ of the universities that are among the first 100 places in the world rankings. At the same time, the same countries attract 8 out of 10 international students of Higher Education and host $90 \%$ of the top $500 .{ }^{33}{ }^{3} 34$ Despite the fact that universities are growing fast in South East Asia, especially in China, Singapore or Japan, still the best universities of the world are concentrated in few occidental countries, and the gap between developed and poorest countries is becoming worst. As Altbach, Reisberg and Rumbley have confirmed: "the inequalities among nations' higher education systems has increased in the last 10 years". 35

These differences are notable at the international level where the central countries benefit from the production of scientific knowledge, while the peripheral countries are deprived of access to primordial cognitive goods on transcendental topics such as new medical, agricultural or educational material. The cognitive gap (Knowledge Divide) and the scientific gap are evident between the countries of the North and those of the South, but it also manifests itself internally in each society. The emergence of this gap has led UNESCO to rise, with great concern, whether the world is heading towards a dissociated society where knowledge is distributed unequally: "There is a real scientific gap that separates" science-rich "countries from others. The vocation of science is universal, but scientific advances seem to be the exclusive part of the planet. Several regions of the world suffer in this area from a considerable delay, which hinders the development of research". ${ }^{36}$

This phenomenon is having an immense impact on the way science and knowledge are distributed on a global scale and in the way that it affects and deepens other previously existing social gaps. While, on one hand, it is thought that the discoveries and scientific-technological applications generated in the university can bring enormous social benefits helping to combat great challenges of humanity, on the other hand, there is concern about the unequal way in which it is distributed and the consequences that it will have in the future. Undoubtedly, open

33 Jose Brunner, "Globalización de la Educación Superior: Critica de su figura ideological." RIES, Revista Iberoamericana de Educación Superior (2010): 77. 2017.

${ }^{34}$ Shanghai Ranking Consultancy. The 2017 Academic Ranking Of World Universities.

${ }^{35}$ Philip Altbach, Liz Reisberg, and Laura Rumbley. "Tracking a global academic revolution." Change March/April (2010): 33.

${ }^{36}$ UNESCO, Towards Knowledge Societies. UNESCO World Report, 183. 
inequality has important social, political, economic and educational consequences, and represents one of the most important challenges of the university in the international system.

\section{Reconfiguration and adaptation}

The new international context of changes and transition in which the university is inserted and the demands and challenges it faces have forced the university to take quick decisions to successfully adapt to the renewed global framework. As Arimoto mentions: "Unless the university responds to the internal and external criticisms and pressures by carrying out thorough reforms, it will be impossible to build universities that can meet the needs of the new era". ${ }^{37}$ For this, the university has had to rethink its interests as an organization and initiate a process of reconfiguration appealing to its historical flexibility, adaptability and international vocation as main strategies.

Considering this new global context, the university has begun to implement a series of strategic actions with the express purpose of adapting as soon and as well as possible to the new international context. Among the main strategies it is possible to highlight the following:

\section{1) Looking for new funding sources}

Confronted with growing number of students and reduction of funding, the university has begun to look for new funding sources that allow it to continue functioning as a central actor in the production and transmission of scientific knowledge. Since the seventies, although much more accelerated in recent decades, many universities have seen their public budgets reduced, which has threatened the very sustenance of the institutions and forced them to seek alternative financing to survive. Therefore, the university has begun to develop strategies that include the privatization and commercialization of the products and services that higher education generates and that it can offer to the market. This is what Slaughter and Leslie have called Academic Capitalism ${ }^{38}$ and represents the use that universities make

37 Akira Arimoto, "Globalisation and Higher Education Reforms: The Japanese Case" In Higher Education in a Globalizing World Higher Education Dynamics, ed. Jürgen Enders and Oliver Fulton (Vol 1, Springer, Dordrecht, 2002), 127.

${ }^{38}$ Slaughter and Leslie, Academic capitalism: Politics, policies, and the entrepreneurial university. 
of their only real asset, the human capital of their academics and the scientific knowledge generated by them, to increase their income.

\section{2) Internal reconfiguration}

The university has also initiated a strategic process of internal restructuring in the search for higher levels of efficiency and modernization that will allow it to face the multiple challenges to which it is subjected. In this sense, it is possible to identify four main areas where substantial changes are observed.

Firstly, in the administration, new forms of management specific to the field of business have been incorporated. Many universities, especially public institutions, have developed internal bureaucracies over time, similar in many cases to state machinery that assume a central role in the daily management of the organization with their own interests and wills. What is at issue now is to reconfigure these administrations to make them more efficient and productive with the aim of being able to compete with other educational institutions and with other international actors interested in knowledge.

Secondly, in the academic staff, there has also been a reconfiguration of strategies with the aim of achieving an academic offer and a product more attractive to the needs of the higher education market. Among the multiple actions that are carried out, the following stand out: a) strengthen and adapt the academic offer to the new socioeconomic realities; b) increase the profile and international reputation in order to attract the most brilliant professors, researchers and students; c) stimulate the arrival of funding sources; d) increase the quality of education to offer a better academic offer; e) diversify their students, faculty, and staff, to show intercultural skills and competencies; f) establish networks and strategic alliances with international actors; and, g) link with actors from their local environment to establish cooperative ties. ${ }^{39}$

Thirdly, in the research area, projects and research developments have been diverted to those scientific areas where there is greater interest on the part of the new funding sources. Because public funds for research have decreased in recent years, much of the applied research has turned to the search for private funds, which demand greater attention and focus on scientific areas that generate innovations

39 Jane Knight, "Internationalization: Concepts, Complexities and Challenges," in International Handbook of Higher Education, ed. James Forest and Philip Altbach (Chapter 11. Volume 18. Dordrecht: Springer, 2006): 207-227 
applicable to the market. However, the main source for fundamental research is still provided by the university.

Lastly, in its own infrastructure, there is a strong commitment to expand and modernize its building facilities. The development of infrastructures fulfills a double objective: on the one hand, new and modern infrastructures have a key role in the production of new knowledge and in the attraction of prestigious professors and researchers; and, on the other, because competitive logic forces universities to offer their academic product to the market in the best possible way, and that includes new generation infrastructures.

3) Encouraging interuniversity cooperation

The new global context has allowed and stimulated the cooperative links among higher education institutions. Essentially, the phenomenon of interuniversity cooperation refers to the interaction and horizontal collaboration between universities. This phenomenon is not new and has been part of the work of many universities for centuries, however, at present, with more space for own initiatives, universities are using this strategy to expand their links, boost their autonomy and improve their positioning in the international system..$^{40}$

The main foundation of the international cooperation of the universities is based on the collaboration and complementarity of their capacities for the realization of joint activities and the achievement of common interests and benefits. The university has found in mutual cooperation an excellent mechanism to obtain shared benefits in very varied topics, such as the institutional organization, establishing agreements on administrative management policy; strengthening and institutional projection at the national, regional and international levels; the improvement of the educational offer of degree, postgraduate, continuous and online, through joint programs; the training and specialization of researchers and scientific research processes; and, the increase of the extension and transfer of scientific and technological knowledge to other social actors. Among the main lines of action, Beneitone et al highlight four main sectors: i) student mobility; ii) the mobility of professors and researchers; iii) the formation of networks and joint academic programs; and iv) the coordination and internationalization of the academic curriculum.

${ }^{40}$ Altbach, Reisberg, and Rumbley. “Tracking a global academic revolution.”, 33. 
This new model sees cooperation as a key aspect of institutional development and the process of cooperation of the university that is now carried out through bilateral and multilateral agreements, such as networks or consortiums. ${ }^{41}$ Interuniversity cooperation has become a strategy and an instrument of great value for universities if they want to survive the new global dynamics of the $21^{\text {st }}$ Century. As pointed out by Moreno Alegre and Albáizar Fernández:

Universities increasingly seek strategic alliances and interuniversity cooperation formulas (networks, associations, consortiums, societies) that give them a greater ability to attract and retain talent (both of students and professors), a more prominent international presence, a better use of resources and, ultimately, a greater ability to compete in an increasingly demanding national and international panorama increasingly demanding. ${ }^{42}$

\section{4) Boosting internationalization}

The new context of boom of the globalization has led the university to promote internationalization as a strategy to adapt to the new global system. Considering its historic universal and international vocation, it is not strange that the university is promoting internationalization as a strategy to successfully face the new global context. In the words of Beneitone et al: "University internationalization is the transformative response of the academic world to globalization". ${ }^{43}$ The university has found in the internationalization a very useful tool to link harmoniously and strategically with other actors and, at the same time, strengthen its position within the international system.

The intensification of the internationalization processes of the university opens the doors to a new scenario for the university where it interacts with a greater variety of international actors (states and non-states) with which it establishes a greater number and modality of interactions. The rise in these relationships has increased the complexity of the links (cooperation, conflict, competition, hegemony) and, at the same time, stimulated the emergence of new processes and

${ }^{41}$ Jesús Sebastián, Cooperación e internacionalización de las universidades (Buenos Aires: Biblos, 2004)

42 Juan Manuel Moreno Alegre and Alfredo Albáizar Fernández, "La tercera misión de la Universidad," in Libro Blanco de la Universidad Digital 2010, ed. Jaime Laviña Orueta and Laura Mengual Pavón (Madrid: Fundación Telefónica, 2008), 91.

${ }^{43}$ Pablo Beneitone et al., eds. Reflection on and Outlook for Higher Education in Latin America. (Bilbao: University of Deusto - University of Groningen, 2007), 12. 
phenomena at the global level (knowledge governance, scientific gap, educational innovations, etc.).

The cooperation of the university with other international actors is not something new, but, in recent years, it has been extended and intensified. The links of the university with the States and companies have become one of the cooperative relations that have deepened more as a product of the new interpretations that consider that the production of knowledge and innovation are a direct consequence of the interactions between those actors. Increasingly, countries and regions choose to establish public policies aimed at articulating and coordinating the tasks of these three actors with the goal of stimulating economic and social development. These new interactions of the university with the State and the company are framed under the new knowledge production model called Triple Helix.$^{44}$ The key here is to stimulate cooperation and the complementary link among the actors with the aim of developing more and better scientific knowledge through a process that benefits all parties equally (win-win situation). This cooperative strategy with central actors of the world order supposes for the university to assume a more protagonist role and to be linked as a pair with the other two central actors of the international system: States and Companies. The university contributes with researchers, expert knowledge, infrastructures and laboratories and in exchange receives subsidies from the State and funds from the Companies to expand the production of new knowledge.

\section{5) The revolution of online education}

Finally, a new adaptation and reconfiguration strategy for universities has arisen because of the scientific-technological advances of the digital information and communication media. This is the rise of e-learning that is transforming the traditional teachinglearning process and that promises to completely revolutionize the educational field..$^{45}$

In recent years, the university has begun to use the new digital tools through a wide range of possibilities and modalities: from courses that use websites only as a complement to traditional face-to-face education,

${ }^{44}$ Henry Etzkowitz and Loet Leydesdorff, Universities and the global knowledge economy: a triple helix of university-industry-government relations.

45 The concept of e-learning or online education is understood as: "the use of information and communication technologies to improve and support learning in tertiary education" (OECD, 2007). 
through blended courses that have teaching methods based on different interactions on the internet (blended learning), up to the offer of teaching completely online. In this context of online education boom Massive Open Online Courses (MOOCs) are creating great expectations. ${ }^{46}$ Many universities, some of them considered World-Class, have started to offer courses on online platforms, allowing students from anywhere in the world to access them for free or for a very small amount of money. Since 2011, MOOCs have experienced exponential growth both in the offer of courses and in the interest of students. Currently, 800 universities around the world offer nearly 9400 online courses. ${ }^{47}$

The development of MOOCs and the growth of online education in recent years are presented as new global strategies of the university to strengthen its role as a transmitter of knowledge. Although the challenges that lie ahead are multiple and complex (quality control, financial viability, global connectivity, professor role, etc.) the possibilities offered by this new modality using new digital technologies have the potential to democratize teaching reaching more places and more people around the planet, which can represent a true educational revolution in the $21^{\text {st }}$ Century.

\section{Conclusion}

The university has occupied a relevant space as a global actor within the international system in recent centuries. Although many times its role and influence have gone unnoticed, even for analysts and researchers, its durability and its strategic role as a producer and transmitter of scientific knowledge has positioned it as one of the main actors in the international system.

Since the last decades of the $20^{\text {th }}$ Century, the world has entered a vertiginous path of transformation, driven by multiple and profound global processes that, in parallel, have been operating within the world order and have generated very significant changes in all parameters of the international system (new actors, interactions, processes and global agenda of topics).

These strong changes in the world order at the beginning of the $21^{\text {st }}$ Century confront the university to new and powerful challenges because of

46 The acronym MOOC was coined in 2008 by Dave Comier and Bryan Alexander to refer to a new type of courses that are online (taught through the internet), open (anyone with internet access can participate) and mass (no limit of registration).

${ }^{47}$ Dhawal Shah, "By The Numbers: MOOCS in 2017”, Class central, January 2018. 
the impact that those global changes are having on the university are multiple and profound: new actors that threaten their traditional role; reduction of their margins of autonomy; assignment of new roles and functions; insertion in the competitive logic, and the increase in inequalities between universities.

Faced with this convulsive context, the university has not remained immobile but, on the contrary, has begun an important process of reconfiguration and adaptation to the new times through multiple strategies of action. These include the search for new sources of financing, the promotion of internationalization processes, the use of interuniversity cooperation as a growth mechanism, the use of new technologies through online education and a profound process of internal reconfiguration that allows it to adapt to the new international context. All these actions have the same strategic objective: to improve the adaptation and positioning of universities in the new international system of the $21^{\text {st }}$ Century.

Historically, transitions from one international order to another have meant a rebalancing of systemic power, and the rise and fall of different actors within the world order. For that reason, the international system of the $21^{\text {st }}$ Century opens new questions about the future of the university as an international actor: the main dilemma remains whether this new stage will mean an opportunity for the university to assume new and relevant functions at international level, or if, on the contrary, it will be besieged by threats and pressures that erode its global role.

Any response to these challenges seems to be hasty, however, and as it emerges due to this investigation, despite the deep systemic changes that operate in the current order, and the strong impact of those trends on higher education, the university has begun complex processes of reconfiguration and adaption to the new international system seeking to become one of the most relevant actor in the new international system of the $21^{\text {st }}$ Century.

\section{Bibliography}

Altbach, Philip. "Perspectiva comparada para la educación superior en el Siglo XXI." Revista Pensamiento Universitario. Año 6. Nro. 8 (1999): 3-12.

- "Globalization and the University: Realities in an unequal world." In International Handbook of Higher Education, James Forest and Philip Altbach. Chapter 8. Volume 18. Dordrecht: Springer, 2006.

Altbach, Philip, and Jane Knight. "The Internationalization of Higher Education: Motivation and Realities." Journal of Studies in International Education 11 (2007): 290-304. http://jsi.sagepub.com/content/11/3-4/290. 
Altbach, Philip, Liz Reisberg, and Laura Rumbley. "Tracking a global academic revolution." Change March/April (2010): 30-39.

Arimoto, Akira. "Globalisation and Higher Education Reforms: The Japanese Case." In Higher Education in a Globalising World. Higher Education Dynamics, edited by Jürgen Enders and Oliver Fulton, 127-140. Springer, Dordrecht, 2002:

Bauman, Zygmunt. Liquid modernity. Cambridge: Polity Press, 2000.

Beneitone, Pablo, et al., (eds). Reflection on and Outlook for Higher Education in Latin America. Bilbao: University of Deusto and University of Groningen, 2007.

Breton, Gilles, and Michael Lambert. Universities and Globalization: private linkage, public trust. Paris: UNESCO, 2003.

Brunner, Jose. "Globalización de la Educación Superior: Critica de su figura ideological.” RIES, Revista Iberoamericana de Educación Superior (2010): 75-83.

Castells, Manuel. Communication power. NY: Oxford University Press, 2009.

Dallanegra Pedraza, Luis. Tendencias del Orden Mundial: Régimen Internacional. Buenos Aires: Ediciones de la Universidad, 2001.

—. Reformulación del Orden Mundial: El Fin de una "Macro-Etapa”. Buenos Aires: Ediciones de la Universidad, 2003.

de Sousa Santos, Boaventura. La Universidad en el Siglo XXI. Para una reforma democrática y emancipadora de la universidad. Buenos Aires: Laboratorio de Políticas Públicas y Miño y Davila, 2005.

Enders, Jürgen, and Oliver Fulton. Higher Education in a Globalising World: International Trends and Mutual Observation A Festschrift in Honour of Ulrich Teichler. Dordrecht: Springer Science \& Business Media, 2002.

Enders, Jürgen. "Higher education, internationalization, and the nation-state: Recent developments and challenges to governance theory." Higher education, Volume 47, Issue 3 (2004): 361-382.

Etzkowitz, Henry, and Loet Leydesdorff. Universities and the global knowledge economy: a triple helix of university-industry-government relations. London: Pinter, 1997.

Foucault, Michel, The archeology of knowledge. New York: Pantheon Books, 1972. Forest, James, and Philip Altbach. In International Handbook of Higher Education. Dordrecht: Springer, 2006.

Horowitz, Michael, and William White-Burke. "Academia can be an important vanguard of the Fourth Industrial Revolution”. World Economic Forum, 19 Jan 2018.

Innerarity, Daniel. La democracia del conocimiento. Por una sociedad inteligente. Barcelona: Paidós, 2011.

Keohane, Robert, and Joseph Nye. Power and interdependence. London: Longman, 2001.

Kerr, Clark. The Uses of the University. Cambridge: Harvard University Press, 2001.

King, Roger. "The contemporary University." In The University in the Global Age, edited by Roger King, 1-27. Basingstoke: Palgrave MacMillan, 2004.

Knight, Jane. "Internationalization: Concepts, Complexities and Challenges." in International Handbook of Higher Education, edited by James Forest and Philip Altbach, 207-227. Dordrecht: Springer, 2006. 
Moreno Alegre, Juan Manuel, and Alfredo Albáizar Fernández. “La tercera misión de la Universidad." In Libro Blanco de la Universidad Digital 2010, edited by Jaime Laviña Orueta and Laura Mengual Pavón, 83-101. Madrid: Ariel and Fundación Telefónica, 2008.

OECD y EUROSTAT. Manual de Oslo. Guía para la recogida e interpretación de datos sobre innovación. España: Grupo Tragsa, 2006.

OECD. Science, Technology and Innovation Indicators in a Changing World. Responding to policy needs. Paris: OECD, 2007.

- Education at a Glance 2016: OECD Indicators. Paris: OECD, 2016.

. OECD Science, Technology and Industry Scoreboard 2017: The digital transformation. Paris: OECD, 2017.

Quintanilla, Miguel. "La investigación en la sociedad del conocimiento." Revista CTS Vol. 3, núm. 8, abril (2007): 183-194.

Rolfe, Gary "Cardinal John Henry Newman and 'the ideal state and purpose of a university': nurse education, research and practice development for the twentyfirst century", Nursing Inquiry. 19 (2012): 98-106.

Schwab, Klaus. The Fourth Industrial Revolution. New York: Crown Business, 2016.

Sebastián, Jesús. Cooperación e internacionalización de las universidades. Buenos Aires: Biblos, 2004.

Shah, Dhawal. "By The Numbers: MOOCS in 2017." Class central, January 2018. https://www .classcentral.com/report/mooc-stats-2017/

Shanghai Ranking Consultancy. The 2017 Academic Ranking Of World Universities. 2017. http://www.shanghairanking.com/ARWU2017.html

Slaughter, Sheila, and Larry Leslie. Academic capitalism: Politics, policies, and the entrepreneurial university. Baltimore: Johns Hopkins University Press, 1997.

Sporn, Barbara. "Governance and Administration: Organizational and structural trends." In International Handbook of Higher Education, edited by James Forest and Philip Altbach, 141-157. Dordrecht: Springer, 2006.

Todt, Oliver. "La gobernanza tecnocientífica en la Unión Europea." Revista CTS Vol. 3, $\mathrm{N}^{\mathrm{o}}$ 7, septiembre (2006): 21-42.

UNESCO. Towards Knowledge Societies. UNESCO World Report. Paris: UNESCO, 2005.

- 2009 World Conference of Higher Education: the new dynamics of higher education and research transformation and development. (Final Report. 5 to 8 July 2009. Paris: UNESCO, 2009).

- UNESCO Science Report: Towards 2030. Paris: UNESCO Publishing, 2015.

Wallerstein, Immanuel. Geopolitics and Geoculture: Essays on the Changing WorldSystem. Cambridge: Cambridge University Press, 1991.

- (coord.) Open the Social Sciences: Report of the Gulbenkian Commission on the Restructuring of the Social Sciences. Stanford: Stanford University Press, 1996.

WORLD SCIENCE FORUM. Declaration of the 8th World Science Forum On Science For Peace. Text adopted on 10 November 2017, Dead Sea, Jordan. 


\section{About the author}

FRANCISCO DEL CANTO VITERALE (francisco.delcanto@fresno.edu / fdelcanto@jhu.edu) holds a PhD in International and Intercultural Studies from the University of Deusto, Spain (2014). He is currently Project Coordinator at Fresno Pacific University (US); Visiting Professor in the Global and International Studies, MA Program at University of Salamanca (Spain); Director of Global and International Studies: Science, Tech and Innovation, MA Program at University of Salamanca (Spain); and Visiting Researcher in the Center for Systems Science and Engineering at Johns Hopkins University (US). He has carried out postdoctoral research at the Systems Institute, School of Engineering at Johns Hopkins University and Massachusetts Institute of Technology (MIT). His core areas of knowledge are Global and International Studies, with a specialization in the intersection between Science, Technology, Innovation, and Higher Education and International Studies. His research focuses on the use of interdisciplinary and systems approaches to analyze complex data, especially on issues connected to science, tech, innovation and higher education and its impact in the international system. Finally, he also has a broad expertise and experience in Latin American Studies, International Migration, Diversity and Intercultural Studies, Political Science, International Political Economy, Foreign Policy, and Advanced Social Research Methods. 


\title{
University as a global actor in the international system of the $21^{\text {st }}$ Century
}

\author{
Francisco Del Canto Viterale
}

doi: http://dx.doi.org/10.18543/tjhe-6(1)-2018pp169-198

Received: 27.09 .2018

Accepted: 12.11.2018

\section{Copyright}

Copyright for this article is retained by the Publisher. It is an Open Access material that is free for full online access, download, storage, distribution, and or reuse in any medium only for noncommercial purposes and in compliance with any applicable copyright legislation, without prior permission from the Publisher or the author(s). In any case, proper acknowledgement of the original publication source must be made and any changes to the original work must be indicated clearly and in a manner that does not suggest the author's and or Publisher's endorsement whatsoever. Any other use of its content in any medium or format, now known or developed in the future, requires prior written permission of the copyright holder. 